\title{
Analisis Penggunaan Media YouTube dan Instagram pada Anggota KelompokSuporter Sriwijaya FC dalam Mengonsumsi Informasi
}

\author{
Muhammad Fajar Wiko, Bayu Hardiono, Zakaria Wahab \\ Magister Manajemen Universitas Sriwijaya, Palembang, Indonesia \\ (jarwiko@gmail.com)Pendidikan Olahraga Universitas Bina Darma, \\ Palembang, Indonesia \\ Fakultas Ekonomi Universitas Sriwijaya, Indonesia
}

\begin{abstract}
The study, entitled Analysis of the Use of YouTube and Instagram Media on Members of the Sriwijaya FC Supporter Group in Consuming Information, aims to determine the relationship between the profile and behavior of members of the Sriwijaya FC supporter group in using YouTube and Instagram as social media to consume information about their team. The method used in this research is descriptive-quantitative with crosstab analysis and chi-square test on SPSS software. The data in this study were collected through a questionnaire (google form) to 100 representatives from three members of the Sriwijaya FC supporter group, namely Singa Mania, Sriwijaya Mania, and Ultras Palembang. The results of this study indicate that duration on YouTube and audience involvement on Instagram are related to the efforts of members of the supporter's group to consume information about Sriwijaya FC.
\end{abstract}

Keywords: Profile, Behaviour, Member of Sriwijaya FC Supporter, YouTube, Instagram, Information Consumption

\section{PENDAHULUAN}

Manusia bisa mendapatkan informasi melalui media massa. Media Massa yang dikenal oleh masyarakat untuk mengidentifikasi pers. Di Indonesia, televisi berada di peringkat teratas dalam penetrasi kepada masyarakat yang mencakup 96 persen dari jumlah penduduk di Indonesia. Proses komunikasi melalui media massa dianggap efektif dan mampumenyebarluaskan informasi kepada masyarakat karena dilakukan secara melembaga dan ditujukan kepada khalayak dan bersifat massal, seperti yang disampaikan oleh Wiryanto (2004). Namun saat ini media massa ini digeser oleh kehadiran media sosial yang lebih bisa diterima oleh generasi saat ini. Media - media penggeser media konvensional seperti televisi, Koran dan radio, dikenal dengan sebutan 'media baru'. Media baru ini berkembang dengan memanfaatkan teknologi

*corresponding authors e-mail :jarwiko@gmail.com Online ISSN: 2721-4230 | Print ISSN: 2721-4281 
informasi dan jaringan internet, contohnya, web, blog, online social network, online forum dan lain-lain yang didukung penggunaan komputer. Meningkatnya kebutuhan informasi, komunikasi dan keterlibatan audiens dalam media baru ini masuk kedalam era yang disebut sebagai era interaktif. Hal ini dijelaskan oleh Everett.

Rogers (Abrar, 2003) dimana era interaktif ini merupakan bagian dari empat era perkembangan komunikasi, yang dimulai dari era komunikasi tulisan, era komunikasi cetak, era telekomunikasi, dan era komunikasi interaktif yang menaungi media baru. Manurut Denis McQuail (2011), adanya saling keterhubungan, akses luas, berkarakter terbuka, ada dimana- mana dan interaktif merupakan ciri-ciri media baru. Berita dalam jaringan (online) dan media sosial seperti yang dikenal secara luas saat ini yaitu Facebook, Instagram, YouTube, Twitter, dan Tumbler juga termasuk kedalam bagian dari media baru tempat masyarakat mendapatkan informasinya.

Media sosial sebagai salah satu bagian dari media baru memberikan dampak besar bagi konsumsi informasi di tengah masyarakat saat ini. Seperti YouTube yang saat ini disebut sebagai salah satu database video yang paling populer di dunia internet. Youtube dengan fitur-fitur kemajuan teknologi yang dimilikinya dianggap yang paling mampu memenuhi kebutuhan informasi penggunanya.

Selain YouTube, media sosial yang saat ini juga tengah meningkat pamornya adalah Instagram. Berdasarkan statistik yang dirilis oleh NapoleonCat, perusahaan analis media sosial yang berbasis di Warsawa, Polandia, jumlah pengguna Instagram di Indonesia hingga bulan Mei 2020 mencapai 69.270.000. Jumlah ini merupakan 25,3 \% dari seluruh populasi Indonesia yang saat ini mencapai 260.000.000 jiwa. Hadirnya media sosial (media baru) ini tak terlepas dari kebutuhan masyarakat akan informasi. Seperti dijelaskan Voight (Krikelas,1983) terdapat tiga hal yang mendasari kebutuhan informasi, yaitu Kebutuhan untuk menyelesaikan suatu penelitian ilmiah, kebutuhan yang timbul dari pekerjaannya maupun profesi, dan kebutuhan yang relevan dengan subyek tertentu yang menjadi perhatian seseorang. Ia juga menyimpulkan bahwa kebutuhan informasi atau information need ini merupakan pengakuan ketidaktahuan dan ketidakpastian dalam diri manusia yang mendorong seseorang untuk mencari informasi.

Dari sekian banyak jenis informasi, salah satu yang paling dicari masyarakat di media sosial adalah informasi mengenai olahraga. Seperti dalam penelitian yang dilakukan oleh Annisa Inggita (2014), dimana hasilnya menunjukkan jika kategori video musik dan video olahraga pada channel YouTube semakin digemari. Sesuai dengan objek penelitian ini, kota Palembang memiliki salah satu klub sepakbola yang berprestasi di Indonesia yaitu Sriwijaya FC dimana informasi mengenai klub sepakbola ini selalu dicari terutama oleh anggota kelompok suporter Singa Mania, Sriwijaya Mania dan Ultras Palembang.

Sebagai media baru, YouTube yang saat ini dikenal luas oleh masyarakat, cenderung memberikan pengaruh signifikan terhadap peningkatan konsumsi informasi seperti 
dalam beberapa penelitian yang dilakukan oleh Julian (2015), M Farhan (2018), Kevin Mangole (2018), Haris Dawana (2019), Yunus Winoto (2019), dan Zikri Fachrul (2020). Begitu pula dengan Instagram yang kini menjadi salah satu sumber informasi masyarakat. Penelitian-penelitian terkait peningkatan konsumsi informasi melalui Instagram telah dilakukan diantaranya oleh Desi Endah (2017), Difa Nurhasna (2018), Edy Juliyanto (2018), Helen (2018), dan Vereen Monica (2019). Oleh sebab itulah, berdasarkan gambaran yang telah diuraikan sebelumnya, peneliti tertarik untuk melakukan penelitian yang berkaitan dengan konsumsi informasi mengenai Sriwijaya FC pada anggota kelompok suporter dengan judul "Analisis Penggunaan Media YouTube dan Instagram pada Anggota Kelompok Suporter Sriwijaya FC Dalam Mengonsumsi Informasi."

\section{KAJIAN LITERATUR}

\section{Pengertian Profil dan Perilaku}

Menurut Kamus Besar Bahasa Indonesia (KBBI), profil merupakan ikhstisar dari sesutu hal yang khusus untuk diketahui atau bisa diartikan sebagai karakteristik yang dalam penelitian ini akan menunjukkan karakteristik anggota kelompok suporter Sriwijaya FC. Karakteristik ini dibagi dalam Jenis Kelami, Usia, Tingkat Usia dan Pekerjaan. Sementara Perilaku menurut (Sunyoto,2011) mengungkapkan jika perilaku konsumen (Consumer Behaviour) adalah kegiatan-kegiatan individu yang secara langsung terlibat dalam mendapatkan dan menggunakan barang-barang atau jasa yang didalamnya termasuk proses pengambilan keputusan dalam menentukan kegiatan-kegiatan itu.

\section{Indikator Profil dan Perilaku}

Terdapat tiga dimensi sebagai indikator pada perilaku konsumen menurut Griffin (Sopiah dan Sangadji, 2013). Indikator ini juga berlaku pada anggota kelompok suporter yang dalam penelitian ini dianggap sebagai konsumen dari produk informasi mengenai Sriwijaya FC, yaitu :

\section{a. Stimulus Pemasaran dan Stimulus Lain}

Stimulus yang dijalankan produsen atau pemasar, bisa berupa strategi pemasaran (produk,harga,tempat,promosi), dan stimulus lain yang berupa kondisi ekonomi, politik, teknologi, budaya yang dirancang oleh pemasar untuk memengaruhi dan memotivasi perilaku konsumen agar mau melakukan pembelian produk.

b. Kotak hitam konsumen

Dimensi kedua dari model perilaku konsumen adalah kotak hitam konsumen, yang mencakup (a) karakteristik konsumen dan (b) proses pengambilan keputusan konsumen. Contoh karakteristik konsumen adalah jenis kelamin, umur, tingkat pendidikan, penghasilan, kelas sosial, budaya, dan sebagainya. Proses pengambilan keputusan konsumen dimulai dengan dirasakannya beberapa masalah, yaitu kebutuhan dan keinginan yang belum terpuaskan, pencarian informasi, evaluasi,

\footnotetext{
*corresponding authors e-mail :jarwiko@gmail.com Online ISSN: 2721-4230 | Print ISSN: 2721-4281 
pembuatan keputusan pembelian, dan tindakan pasca pembelian.

c. Respon konsumen

Dimensi ketiga dari model perilaku konsumen adalah respons konsumen terhadap stimulus produsen/pemasar.Respons konsumen bisa berupa tindakan membeli, menggunakan atau tidak membeli produk yang ditawarkan produsen atau pemasar.

\section{Pengertian YouTube}

Saat ini YouTube yang mendominasi mesin pencarian. Memiliki konten sendiri dan menyediakan video apapun bagi masyarakat. YouTube juga dapat berfungsi secara privat atau publik. Bahkan saat ini YouTube telah menjadi budaya internet di tengah masyarakat. Diungkapkan Jason Tedjasukmana, Head of Corporate Communications at Google Indonesia pada 2011 lalu, ada tiga fakta yang dijumpai dari penelitian etnografi terkait YouTube. Pertama, menonton YouTube merupakan pengalaman yang sangat pribadi. Kedua, konten yang disajikan YouTube membantu penonton memperluas pikiran mereka mengenai siapa diri mereka sesungguhnya dan mengajarkan mereka berbagai keterampilan baru. Ketiga, para penonton YouTube terbuka terhadap konten yang disponsori dari para pembuat konten yang mereka percaya. Pernyataan Jason ini didukung oleh studi etnografi yang dilakukan oleh Bruno Moynie (2011) terhadap responden di dua Negara yaitu Indonesia dan Thailand.

\section{Indikator YouTube}

a. $\quad$ Konten (Ketersediaan Informasi)

Menurut kamus besar bahasa Indonesia (KBBI) konten adalah informasi yang tersedia melalui media atau produk elektronik. Konten terdiri dari teks, gambar, audio, video atau gabungan dari keempat item tersebut yang bisa didapatkan pada tayangan YouTube, seperti pada penelitian ini. Menurut John Vivian (2008), Konten video youtube merupakan perwujudan dari komunikasi massa yang dimana di definisikan sebagai proses penggunaan medium massa untuk mengirim pesan kepada audien yang luas untuk tujuan memberi informasi, menghibur, atau membujuk.

b. Durasi (Lama Waktu Penayangan)

Lama waktu penayangan memberi pengaruh bagi audience untuk menonton video YouTube. Mengutip dari laman Minimatters, durasi rata-rata dari 10 video terpopuler di YouTube saat ini adalah 4 menit 20 detik. Video populer terlama berdurasi 9 menit 15 detik dan tersingkat hanya 42 detik. Berdasarkan laporan dari ComScore.com pada Januari 2019, durasi rata-rata video online berada di angka 4,4 menit dan video berdurasi 2-10 menit punya jumlah views yangcukup konsisten (loop.co.id, 2020)

\section{Pengertian Instagram}

Instagram berasal dari kata "insta" dari instan dan "gram" yang berasal dari kata

\footnotetext{
*corresponding authors e-mail :jarwiko@gmail.com Online ISSN: 2721-4230 | Print ISSN: 2721-4281 
"telegram" sehingga menjadi "instan-telegram". Instagram dinilai sangat fokus pada tujuannya untuk menjadi mediator komunikasi melalui gambar atau foto. Gambar atau foto itu diupload ke server Instagram kemudian dihare kepada followers dan server Instagram. Berdasarkan penelitian sebelumnya oleh Wurinanda (2015), Instagram memiliki beberapa karakteristik yaitu memiliki fasilitas mengupload foto dan video, menguntungkan penggunanya karena bisa melihat langsung apapun yang diupload, memuat informasi lengkap melalui caption yang disampaikan serta memiliki fasilitas hashtag (tanda pagar) yang memudahkan penggunanya untuk mencari apa yang diinginkan.

\section{Indikator Instagram}

a. Kualitas Visual Sama halnya dengan YouTube, konten pada Instagram tidak hanya berupa foto atau video tetapi juga menampilkan infografik untuk menunjang ide dari pembuat konten. Infografik yang merupakan bagian dari konten visual ini bertujuan untuk mengurangi kebosanan audience sekaligus memberikan variasi seperti dalam penelitian yang dilakukan oleh Edy Julianto (2018).

b. Keterlibatan Audience

Selain fasilitas like photo, Instagram juga memiliki fasilitas Comment Photo untuk melihat sejauh mana keterlibatan audience. Keterlibatan audience ini merupakan respons yang nantinya menjadi tolok ukur efektifitas akun Instagram tersebut. Melalui fasilitas tersebut, pemilik akun dan audience bisa berkomunikasi dan mendapatkan umpan balik dari setiap postingan di akun Instagram. Keterlibatan audience atau engagement sebagai bagian penting dari efektifitas sebuah media sosial, dijelaskan oleh Luttrel (2019) dalam bukunya yang berjudul Social Media : How to Engage, Share and Connect.

\section{Pengertian Konsumsi Informasi}

Konsumsi informasi seperti dijelaskan Katz, dkk (Severin, 2005) dipengaruhi oleh kebutuhan. Lebih lanjut dijelaskannya, terdapat lima kategori kebutuhan yang mendasari manusia untuk mengonsumsi informasi yaitu (1) Kebutuhan Kognitif, yakni memperoleh informasi, pengetahuan dan pemahaman (2) Kebutuhan Afektif, yang terdiri dari pengalaman menyenangkan, rasa emosional, dan estetis (3) Kebutuhan Integratif personal, yaitu bertujuan untuk memperkuat rasa percaya diri dan status karena memperoleh informasi (4) Kebutuhan Integratif Sosial untuk mempererat hubungan dengan keluarga, teman dan sebagai pergaulan, (5) Kebutuhan Pelepasan ketegangan dan pengalihan.

\section{Kerangka Konseptual Penelitian}

Berdasarkan uraian diatas, maka kerangka konseptual penelitian ini adalah Profil dan Perilaku Kelompok Suporter pada penggunaan media YouTube dan Instagram dalam mengonsumsi informasi mengenai Sriwijaya FC. Hal ini dijelaskan lebih lanjut pada 
gambar dibawah ini :

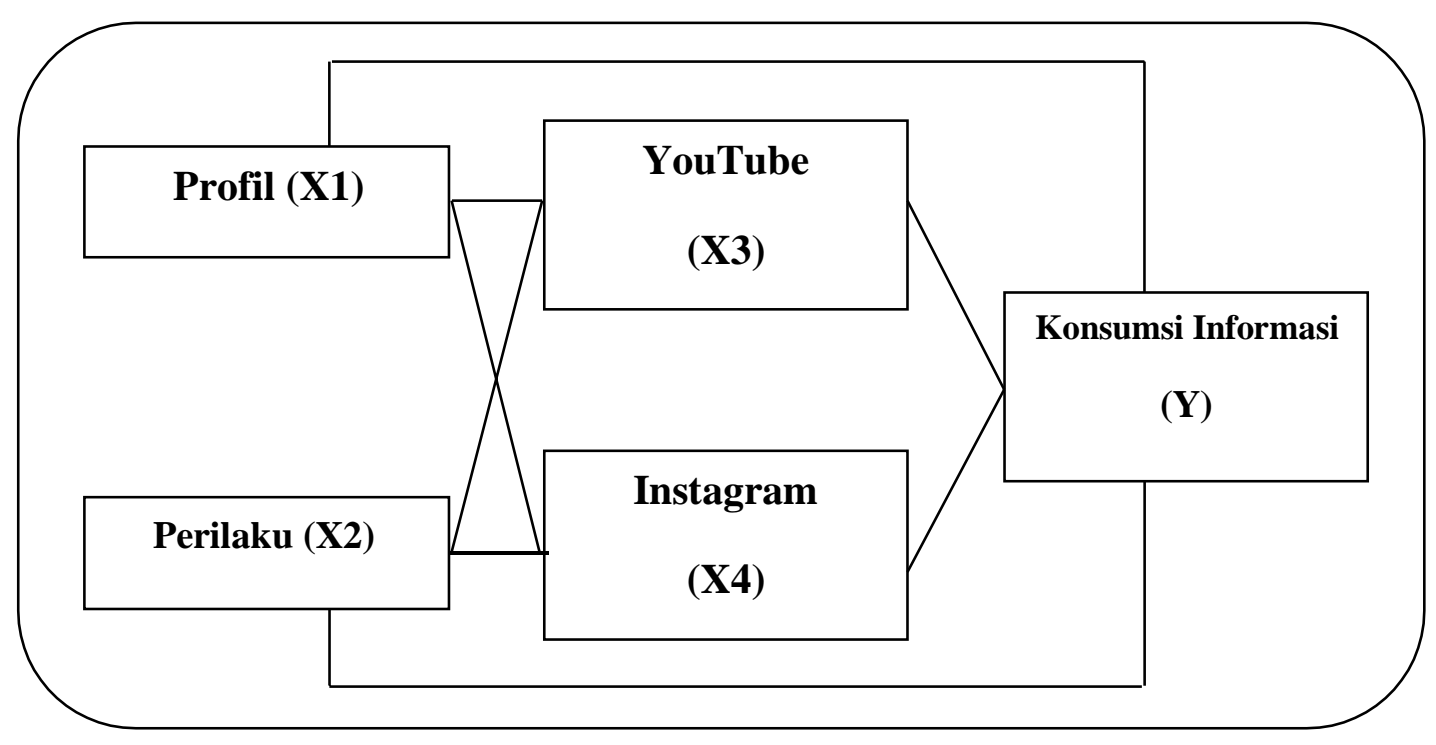

Gambar 1: Kerangka Konseptual PenelitianSumber : Data Penulis 2020

\section{METODE RISET}

Ruang lingkup penelitian ini menganalisis profil dan perilaku anggota kelompok suporter Sriwijaya FC pada penggunaan media YouTube dan Instagram dalam mengonsumsi informasi. Melalui metode riset ini akan dideskripsikan bagaimana hubungan antara variabel penelitian, yaitu : Profil (X1), Perilaku (X2), YouTube (X3), Instagram (X4) dan Konsumsi Informasi (Y).

\section{Populasi dan Sampel}

Populasi menurut (Sugiyono, 2014), merupakan wilayah generalisasi objek atau subjek yang memiliki kualitas serta karakteristik tertentu yang ditetapkan untuk dipelajari dan kemudian ditarik kesimpulannya. Dalam penelitian ini, populasi yang diambil peneliti berjumlah 6.000 orang yang terdiri dari anggota tiga kelompok suporter Sriwijaya FC.

Sementara sampel adalah bagian kecil dari dari populasi, terdiri dari beberapa anggota populasi yang dipilih berdasarkan pertimbangan banyaknya jumlah populasi yang tidak semuanya bisa dipilih. Pada penelitian ini digunakan teknik Probability Sampling yang mengedepankan metode Simple Random Sampling. Dalam penelitian ini, peneliti memperoleh 100 sampel dengan menggunakan rumus Slovin dengan rincian 32 orang anggota Singa Mania, 35 orang anggota Sriwijaya Mania dan 33 orang anggota Ultras Palembang.

\section{Jenis dan Sumber Data}

Penelitian ini menggunakan jenis data kuantitatif yang diukur dalam suatu skala 
numerik atau angka (Sugiyono, 2014). data yang diperoleh dari kuesioner (google form) yang telah disebarkan kepada responden yang dituju yaitu anggota dari tiga kelompok suporter Sriwijaya FC, yakni Singa Mania, Sriwijaya Mania, dan Ultras Palembang.

\section{Identifikasi dan Operasional Variabel}

Terdapat empat variabel bebas dalam penelitian ini, yaitu Profil (X1), Perilaku (X2), YouTube (X3) dan Instagram (X4) dan satu variabel terikat yaitu Konsumsi Informasi (Y). Untuk menjawab hipotesis, peneliti mengajukan 22 pertanyaan yang sesuai dengan kebutuhan danindikator variabel yang dimaksud.

\section{Uji Instrumen}

\section{a. Uji Validitas}

Untuk mengukur instrumen penelitian valid atau tidaknya kuesioner, maka peneliti menggunakan uji validitas. Kuesioner dinyatakan valid apabila pertanyaan yang diajukan menjawab apa yang hendak diukur. Hal ini dapat dilihat dari perbandingan antara nilai $r$ hitung dengan nilai $r$ tabel. Apabila $r$ hitung $>r$ tabel dan bernilai positif, dengan nilai signifikan 0,05 hal itu berarti signifikan sehingga lalu dapat disimpulkan bahwa item pertanyaan tersebut dinyatakan valid, dan sebaliknya.

\section{b. Uji Reliabilitas}

Penelitian bisa disebut reliable (terpercaya) jika instrument penelitian menunjukkan hasil yang sama meski dilakukan pengukuran dalam waktu yang berbeda secara konsisten. Dalam penelitian ini, peneliti menggunakan teknik Alpha Cronbanch dan atau program SPSS (Statistical Product and Service Solutions). Dimana suatu indikator dapat dikatakan reliabel jika nilai alpha $>0,60$.

\section{Analisis Data}

\section{Analisa Crosstab}

Analisa Cross Tab yang digunakan peneliti adalah salah satu analisis korelasional yang bertujuan untuk melihat serta menjelaskan hubungan antar variabel melalui data nominal dan seberapa kuat hubungan tersebut (Santoso,2012). Uji ini merupakan metode analisis berbentuk tabel yang menampilkan tabulasi silang atau tabel kontigensi yang digunakan untuk mengetahui hubungan antar variabel.

\section{Uji Hipotesis}

\section{Uji Chi-Square}

Dalam penelitian ini, peneliti menguji hipotesis dan mengambil keputusan berdasarkan perbandingan nilai Chi-Square sebagai alat uji non-parametrik. Lewat uji ini, peneliti melihat hubungan antar variabel melalui nilai pada baris dan kolom. Dalam membandingkan Chi-Square tabel:

1. Jika Chi-Square Hitung > Chi-Square tabel, maka terdapat hubungan

2. Jika Chi-Square Hitung < Chi-Square tabel, maka tidak terdapat hubungan 


\section{SIMPULAN DAN SARAN}

Berdasarkan hasil analisa dan pembahasan yang telah dijabarkan pada bab sebelumnya, maka dapat disimpulkan bahwa : (1) Terdapat hubungan antara Profil dan Perilaku pada penggunaan media YouTube dan Instagram dalam Meningkatkan Konsumsi Informasi Mengenai Sriwijaya FC, (2) Media sosial Instagram merupakan media yang paling banyak dipilih oleh anggota kelompok suporter untuk mendapatkan informasi mengenai Sriwijaya FC, (3) Anggota kelompok suporter dengan latar belakang yang beragam memiliki kebutuhan informasi dalam jumlah yang juga beragama. Mereka akan berupaya mencukupi kebutuhannya akan informasi melalui media yang beragam pula. Itulah sebabnya, anggota kelompok suporter ini tidak hanya mengikuti akun YouTube dan Instagram resmi yang dikelola oleh manajemen Sriwijaya FC. Akan tetapi, mereka juga mencari dan mencukupi kebutuhan informasinya melalui media massa konvensional dan media sosial lainnya. Anggota kelompok suporter ini juga mengikuti akun YouTube dan Instagram lain, yang dikelola seperti misalnya oleh anggota kelompok suporter, klub sepakbola lain, asosiasi sepakbola (PSSI) untuk mengetahui jadwal pertandingan dan sebagainya.

Berdasarkan hasil penelitian ini, juga terdapat beberapa saran yang bisa dilakukan yaitu sebagai berikut :

\section{Bagi Peneliti}

Hasil penelitian ini bisa menjadi acuan atau titik awal bagi penelitian berikutnya mengenai perilaku anggota kelompok suporter Sriwijaya FC, bahkan secara luas bisa juga dilakukan untuk meneliti anggota kelompok suporter klub sepakbola lain di Indonesia.

Dalam penelitian terkait konsumsi informasi dan media, peneliti berikutnya diharapkan bisa mempertajam indikator pada jenis media yang digunakan sebagai variabel penelitian, seiring dengan berkembangnya teknologi informasi khususnya pada media massa dan media sosial di masa yang akan datang. Sementara bagi penelitian tentang even olahraga, perlu dilakukan penyesuaian variabel yang digunakan untuk jenis kegiatan (even) apa yang dilakukan. Sebab nantinya akan dipengaruhi oleh profil responden yang digunakan dalam penelitian tersebut.

\section{Bagi Manajemen Sriwijaya FC}

Sebagai klub sepakbola yang telah meraih sejumlah prestasi, Sriwijaya FC harus memaksimalkan lagi upaya mengelola informasi melalui media massa dan media sosial. Hasil penelitian menunjukkan jika anggota kelompok suporter mengiginkan informasi secara lengkap, meliputi konten (Isi Informasi) yang berkualitas dan mudah didapat. Anggota kelompok suporter ini juga perlu untuk dilibatkan dalam komunikasi secara langsung ataupun tidak langsung lewat fasilitas yang dimiliki pada media sosial. Misalnya kolom komentar pada akun instagram. Dengan begitu, anggota kelompok suporter ini akan merasa memiliki keterikatan atau hubungan baik dengan klub sepakbola yang mereka dukung. Upaya mendekatkan diri dan menjalin 
komunikasi dengan anggota kelompok suporter ini diharapkan bisa memaksimalkan lagi konsumsi informasi mengenai Sriwijaya FC di tengah prestasi yang sedang menurun saat ini

\section{Bagi Lembaga dan Masyarakat Umum}

Salah satu hasil dari penelitian ini menunjukkan jika sosial media Instagram menjadi yang paling di pilih oleh anggota kelompok suporter dalam mengakses informasi mengenai Sriwijaya FC. Hasil ini bisa dimanfaatkan oleh sponsor untuk melakukan penetrasi dan promosi melalui media sosial instagram resmi milik Sriwijaya FC.

\section{CATATAN AKHIR}

Pada bagian ini peneliti mengucapkan terima kasih yang sebesar-besarnya kepada anggota kelompok suporter Singa Mania, Sriwijaya Mania dan Ultras Palembang, serta manajemen Sriwijaya FC. Terima kasih juga peneliti sampaikan kepada pembimbing Bapak Dr Zakaria Wahab MBA, Bapak Dr Bayu Hardiyono MPd, Kepala Prodi Magister Manajemen Fakultas Ekonomi Universitas Sriwijaya Hj Marlina Widiyanti SE, SH, MM, PhD, Dekan Fakultas Ekonomi Universitas Sriwijaya Prof Dr Mohamad Adam SE, ME. Tak lupa peneliti juga berterima kasih kepada Kementerian Pemuda dan Olahraga Republik Indonesia atas kesempatan yang diberikan untuk mengikuti beasiswa pendidikan ini.

\section{DAFTAR PUSTAKA}

Abrar, Ana Nadya. (2003). Teknologi Komunikasi: Perspektif Ilmu Komunikasi. Yogyakarta: LESFI.

Dawana, Haris. (2019). Pemanfaatan Akun YouTube oleh Humas Kampar sebagai Pusat Informasi. Skripsi. UIN Suska Riau.

Desi Endah Pratiwi dan Doddy Wihardi. (2017). Publikasi Kegiatan Pemerintah Kabupaten Karawang Melalui Instagram. Jurnal paterei vol. 2 No. 3

Difa Nurhasna Ayutiani dan Berlian Primadani. (2018). Penggunaan Akun Instagram sebagai Media Informasi Wisata Kuliner. Jurnal vol. 3 No. 1. Universitas Padjadjaran.

Edy Juliyanto dan Farid Rusdi. (2018). Strategi Penyampaian Informasi Melalui Instagram Dengan Tampilan Infografis di Kementerian Perdagangan RI. Jurnal Universitas Tarumanegara Vol. 2 No. 2. Universitas Tarumanegara.

Fadhlurrahman, M Farhan. (2018). Hubungan Motif dengan Kepuasan Penggunaan YouTube terhadap Santri Pondok Pesantren Al Munawwir Komplek Nurussalam. Thesis. UIN Sunan Kalijaga Yogyakarta.

Helen, Farid Rusdi. (2018). Pengaruh Penggunaan Media Sosial Akun Instagram @Jktinfo Terhadap Pemenuhan Kebutuhan Informasi Followers. Jurnal Universitas Tarumanegara Vol. 2 No. 2. Universitas Tarumanegara. 
Julian Nur Afifur Rohman, Jazimatul Husna. (2015). Situs Youtube Sebagai Media Pemenuhan Kebutuhan Informasi : Sebuah Survei Terhadap Mahasiswa Program Studi Ilmu Perpustakaan. Universitas Diponegoro.

Kevin David B Mangole, Meity Himpong, Edmon R Kalesaran. (2018). Pemanfaatan YouTube dalam Meningkatkan Pengetahuan Masyarakat Desa Paslaten Kecamatan Remboken Minahasa. Jurnal Vol. 6 No. 4. Universitas Sam Ratulangi.

Krikelas, James (1983), "Model of Information Seeking Behavior", Information Seeking Behavior and Technology Adoption: Theories and Trends, h. 82-93.

Luttrel, R. (2019). Social Media : How To Engage, Share And Connect. Journal of Chemical Information And Modeling Vol. 53. Rowman\& Littlefield.

McQuail, Denis. 2011. Teori Komunikasi Massa McQuail, Edisi 6 Buku 1. Jakarta: Salemba Humanika.

Salamah, Ayudithia ArfinsyaYuniar. (2020). Motif Penggunaan Youtube Sebagai Media Informasi Kecantikan Generasi Millenial. Jurnal Komunikasi dan Media Vol. 4. No. 1. Universitas Putra Batam.

Sangadji, Etta Mamang \& Sopiah. (2013). Perilaku Konsumen - Pendekatan Praktis disertai Himpunan Jurnal Penelitian. Yogyakarta: ANDI.

Severin, Werner J dan James W Tankard (2005). Teori Komunikasi: Sejarah, Metode, dan Terapan di dalam Media Massa. Jakarta: Prenada Media

Sunyoto, Danang. 2013. Perilaku Konsumen. Yogyakarta: Center of Academic Publishing Service (APS).

Sugiyono. (2014). Metode Penelitian Pendidikan Pendekatan Kuantitatif, Kualitatif, dan R\&D. Bandung: Alfabeta

Veeren Monica Sanjaya, Gafar Yoetadi. (2019). Tingkat Kepuasan Informasi Kuliner terhadap Penggunaan Instagram @anakjajan. Jurnal Vol. 3 No. 1 Fakultas Ilmu Komunikasi, Universitas Tarumanagara.

Vivian, John. 2008. Teori Komunikasi edisi kedelapan, Jakarta: Prenanda Media Grup. Wiryanto. (2004). Pengantar Ilmu Komunikasi .Jakarta: Grassindo

Wurinanda I. (2015). Efektivitas Promosi Produk Ayam Suwir "sikentung" melalui Twitter. Skripsi. Bogor. Institut Pertanian Bogor.

Yunus Winoto, Diana Indriasari, Saleha Rodiah. (2019). Studi Tentang Perilaku Pencarian Informasi Melalui Youtube Channel Travel Vlogger di Kalangan Mahasiswa. Jurnal Publication Library And Information Science Vol. 3 No. 2 Universitas Padjadjaran

https://loop.co.id/articles/durasi-video-youtube 